\title{
DUTY OF PATERNAL FAMILY MEMBERS IN THE MAINTENANCE OF CHILDREN ACCORDING TO SECTION 73(2) OF ISLAMIC FAMILY LAW (SELANGOR) ENACTMENT 2003
}

\author{
Norazlina Abdul Aziz* \\ Rozlinda Abdullah ${ }^{* *}$ \\ Irini Ibrahim ${ }^{* * *}$ \\ Nurazlina Abdul Raof ${ }^{* * * *}$
}

\begin{abstract}
Section 73 of Islamic Family Law (Selangor) Enactment 2003 provides that it is the duty of the paternal family to provide maintenance to the children in the event of the father's death, missing in action or suffers from any disabilities. However, the efficiency of this provision depends on the understanding and application by the courts and the person who is said to be liable under 'hukum syarak'. Currently there is not many studies conducted on the efficiency of this provision in solving cases where there is a failure to provide maintenance to children in the circumstances stated above. This study analyses the application of section 73 of Islamic Family Law (Selangor) Enactment 2003 with the aim of looking into the efficiency of this section in solving the issue children's maintenance. The study adopts a qualitative method that involves doctrinal study, arm-researcher approach and semi-structured interviews. The provision, scope and jurisdiction of section 73 of Islamic Family Law (Selangor) Enactment 2003 is analysed in detail. The semistructured interview delves into the current practice of the court in the Federal Territories where the views of selected respondents ranging from the judges in the Shariah courts in the Federal Territories, Shariah law
\end{abstract}

* Law lecturer at Faculty of Law, Universiti Teknologi Mara, Shah Alam, Selangor. Email: noraz397@uitm.edu.my.

** Law lecturer at Faculty of Law, Universiti Teknologi Mara, Shah Alam, Selangor. Email: ozlinda@uitm.edu.com.

*** Law lecturer at Faculty of Law, Universiti Teknologi Mara, Shah Alam, Selangor. Email: irini@uitm.edu.my.

**** Law lecturer at Faculty of Law, Universiti Teknologi Mara, Shah Alam, Selangor. Email: nurazlina@uitm.edu.my. 
practitioner, and academics. This study finds that the existing laws are somewhat insufficient in addressing issues of child maintenance and lack of awareness on the claimant (mother and children) on the responsibility of the extended family. The study proposed some recommendations for some reforms of the current law and practice.

Keywords: duties of the paternal family, rights of children to maintenance, Shari'ah Law on rights of children to maintenance.

\title{
TANGGUNGJAWAB AHLI KELUARGA SEBELAH AYAH DI DALAM MEMBERI NAFKAH MENURUT PERUNTUKKAN SEKSYEN 73(2) ENAKMEN KELUARGA ISLAM (SELANGOR) 2003.
}

\begin{abstract}
ABSTRAK
Seksyen 73 Enakmen Undang-Undang Keluarga Islam (Selangor) 2003 memperuntukkan tanggungjawab untuk memberi nafkah kepada waris di sebelah ayah seandainya ayah kandung kanak-kanak itu, mati, hilang atau tidak mampu. Walau bagaimanapun, keberkesanan peruntukan ini bergantung kepada pemahaman mereka yang dikategorikan sebagai bertanggungjawab mengikut hukum syarak serta sejauh mana mahkamah menggunapakai peruntukan ini bagi menjaga kebajikan kanak-kanak yang terlibat. Kajian berkaitan penggunaan peruntukan ini sebagai penyelesaian alternatif kepada pemasalahan ini tidak banyak dijalankan. Oleh kerana itu, kajian ini bertujuan untuk melihat keberkesanan peruntukan seksyen 73 Enakmen Undang-Undang Keluarga Islam (Selangor) 2003 ini sebagai penyelesaian kepada tanggungjawab memberi nafkah kepada kanak-kanak yang terabai di dalam keadaan yang tersebut di atas. Kajian ini menggunapakai kaedah kualitatif yang melibatkan kajian doktrinal, kajian perpustakaan dan temubual separa-struktur. Peruntukan, skop dan bidangkuasa seksyen 73 Enakmen Undang-Undang Keluarga Islam (Selangor) 2003 dianalisa menggunakan kaedah doktrinal dan kajian perpustakaan. Manakala temubual separa-stuktur pula mengkaji tentang amalan semasa Mahkamah Shariah di Selangor melalui perspektif responden yang terdiri daripada hakim Mahkamah Syariah, peguam syarie dan ahli akademik. Kajian ini mendapati bahawa kerangka perundangan yang sedia ada adalah tidak mencukupi di dalam menyelesaikan isu berkaitan nafkah anak dan penuntut di dalam kes seumpama ini (ibu dan anak) kurang berpengetahuan mengenai tanggungjawan keluarga sebelah ayah
\end{abstract}


di dalam isu nafkah terhadap anak. Kajian ini mencadangkan beberapa resolusi untuk pembaharuan undang-undang dan amalan perundangan.

Kata kunci: tanggungjawab waris sebelah ayah, hak kanakkanak menerima nafkah, nafkah anak di bawah undangundang Shari'ah, hak anak untuk nafkah.

\section{INTRODUCTION}

Recent news highlighted heart-wrenching stories of unfortunate children without means of support. ${ }^{1}$ These unfortunate events can come in various forms either by the death of one of the parents, death of both parents, a missing father who is the sole breadwinner of the family or a father that became incapable of working. In such situations, the Shari'ah provides that in the absence of the father, the responsibility to provide for the children of the deceased or missing man falls on the paternal family, while they remain unable to fend for themselves. This position has been embedded in section 73(2) of Islamic Family Law (Selangor) Enactment 2003. Unfortunately, the existence of this provision has not sufficiently been able to address cases of unfortunate children who are left with no proper maintenance. Despite having this provision, there have been reports that there are many abandoned children without means of support. ${ }^{2}$ To date, there is lack of research on the efficiency of this provision in addressing these issues. Thus, this study aims to analyse the application of section 73 of Islamic Family Law (Selangor) Enactment 2003 with the aim of looking into the

1 Ang Tian Tian, "Uncertain Future for Young Children Whose Parents Died in Johor Car Crash", The Newpaper, June, 20, 2018, accessed on February 15, 2019 from https:/www.tnp.sg/news/singapore/fatechildren-whose-parents-died-car-crash-uncertain; Tan Ern Ser, "Beyond the Impact of Divorce on Children, Let's Not Forget Factor Such as Family Environment and Social Class", Today, December 21,2020, accessed on April 30, 2021 from https://www.todayonline.com/commentary/beyond-impact-divorcechildren-lets-not-forget-factors-such-family-environment-and-social.

2 Utusan Online, "Nafkah Anak", Utusan Melayu (M) Bhd, January, 23, 2013, accessed on February 2, 2018 from http://ww1.utusan.com.my/utusan/Bicara_Agama/20130123/ba_03/Nafk ah-anak\#ixzz56Tq9fv00. 
efficiency of this section to solve the issue of children maintenance in specific situations as stated above.

\section{LITERATURE REVIEW}

There is an abundance of literature that discusses the right to maintenance. A majority of these studies focuses on right of maintenance of wives. Aside from that, there are also plenty of studies that venture into the area of child maintenance. Much of the literature ${ }^{3}$ concentrates on the obligation of a father to maintain his legitimate child during period of marriage and after divorce. Where majority of these studies have provided lengthy discussion on the duty of a father to provide for children maintenance, they did not address in depth the issue of child maintenance in the event the father passed away, his whereabouts is unknown or incapable to provide maintenance due to suffering from certain illness. In his study, Zaini Nasohah ${ }^{4}$ for example, comprehensively elaborated on the categories and amount of maintenance imposed on a father. He further emphasized that although the determination of maintenance varies from time to time, due to the changes in lifestyle, the main principle remains the same. This principle relates to the need to balance the ability of the father to afford the claim and the actual needs of the children should always be followed. This study had extensively discussed on the duty of father to

3 Badruddin Hj. Ibrahim and Azizah Mohd, "Hak Anak Terhadap Nafkah Dalam Perundangan Islam: Sejauh Manakah Bapa Bertanggungjawab Menanggung Nafkah Anaknya," 25 Kanun no. 2(2013): 255; Najibah Mohd Zin, Nora Abdul Hak, Azizah Mohd, Normi Abd Malek, Norliah Ibrahim, Roslina Che Soh@ Yusoff, Norainin Md Hashim, Badruddin Ibrahim, Islamic Family Law in Malaysia (Kuala Lumpur: Sweet \& Maxwell, 2016), 121; Najibah Md. Zin, Noraini Hashim, Nora Abd Hak, Roslina Che Soh, Kamilia Ibrahim, Helmi Md Said, “A Baseline Study of the Enforcement of Nafkah Orders in Selangor Syariah Court," Pertanika Journal of Social Science and Humanities, 23(5)(2015): 327326; Raihanah Azhari, Bahiyah Ahmad, Asmak Ab Rahman.(2012). "Penentuan Kadar Kifayah dan Maaruf Nafkah Anak dan Isteri: Kajian terhadap Penghakiman Mahkamah Syariah," Jurnal Syariah, Jilid.2, bil. 2 (2012): 145-162.

4 Zaini Nasohah, "Analisa Keputusan Mahkamah Syariah Dalam Penentuan Kadar Dan Bentuk Nafkah Anak," a paper presented at 3rd International Seminar on Islamic Thought (2018): 289. 
pay for his children's maintenance and the division of maintenance. Nevertheless, it did not address the role of the paternal family to provide maintenance, in the absence of the father.

This issue was dealt with by Najibah Md Zin et al where the authors had discussed the role of the extended family in giving maintenance to the family member. This article clearly explained the duties of extended family member but in relation to the duty to maintain the parents under the civil and Islamic law. The focus of this writing was more on the concept of extended family and the dilution of family unit due to the adoption of an individualistic lifestyle, that has resulted in the abandonment of the duty to maintain parents. The discussion on right of children to be maintained by the paternal family under the Shari'ah was not discussed.

Another study on child maintenance by Raihanah Azhari et al ${ }^{6}$ delved into theological studies on the maintenance of child and wife. It involved a discussion on the important elements in determining the existence of the duty to maintain as specified under the Islamic law. Although this study explained thoroughly the elements of kifayah and maaruf, the study did not touch on the matter in relation to the provision under section 73(2) of Islamic Family Law (Selangor) Enactment 2003. Thus, in contributing to the body of knowledge on children's maintenance, this article will examine the duties of the paternal family to maintain children in the event the father passed away, missing or he is unable to maintain the family under the purview of Islamic Family Law (Selangor) Enactment 2003.

\section{RESEARCH METHODOLOGY}

This research adopts a qualitative method, primarily based on a doctrinal study supported by interviews, workshops and focused group discussions. The doctrinal study is carried out using the library-based approach. This method provides a deeper understanding of the doctrinal content, particularly the current laws, administrative

5 Najibah Mohd Zin, "Regulating the Role of Extended Families in Providing Financial Support under Malaysian Law," International Islamic University Malaysia Journal (IIUMJ) no.16, (2008): 109.

6 Raihanah Azhari, Bahiyah Ahmad, Asmak Ab Rahman, "Penentuan," p. 143. 
regulations and enforcement tools associated with the governance of child maintenance under the Muslim law in Malaysia.

The discussion used the descriptive approach and explanatory approach on the existing law. The aim of the library-based research is to analyse the laws relating to the governance of child maintenance under the Shari'ah in Malaysia. This includes an analysis of existing statutes, administrative regulations, statistics, relevant reports. Aside from that the study is also supported by interviews from officers from the Syariah Court as well as clients of the court. The research also relied on data collected from semi-structured interviews. As well as data mined from the examination of court files. The selection of the interviewees was made by using the purposive approach. The interviews are exploratory in nature as the research seeks to investigate how the interviewees perceived the extent of effectiveness of the existing legal, administrative regulations and monitoring tools. An electronic voice recorder was used throughout the semi-structured interview sessions, with the consent of the interviewees were obtained before they were interviewed. The outcome of this study showcases intensive, detailed and in-depth results, examining the intricacies and complexities within the child maintenance issue.

\section{FINDINGS AND DISCUSSIONS}

\section{The Concept of Maintenance under the Islamic law}

The Arabic word for maintenance is known as nafaqa or al-nafaqa as defined by al-Sharbini (School of Imam Shafie scholar). It is a noun from the word al-infaq which means to spend something, like money. ${ }^{7}$ Nafaqa is also known as money owed by a husband to his wife for maintenance of her needs and those of the household. ${ }^{8}$ The Halsbury law of England defines maintenance to mean the weekly or monthly payments which may be ordered on a decree of divorce or nulling to be made for the maintenance and support of the wife during the joint lives of the spouses and maintenance for children is a similar provision for

7 Rohanee Machae, Abdul Basir Mohamad, Mutsalim Khareng, "Children Maintenance: The Rights in Islamic Family Law and Law of Thailand," Mediterranean Journal of Social Science.vol.6, no.4, (2015): 112.

8 Gisela Webb, Windows of Faith: Muslim Women Scholar Activists in North America, (New York: Syracuse University Press, 2000), 263. 
their benefit. Osborne $\mathrm{J} . \mathrm{W}^{9}$ elaborates maintenance to mean to spend on someone who is obliged for a person to support him or her economically.

The Shari'ah clearly recognizes that maintenance is the essential right of children that is inclusive of food, clothing, residence, some essential services and medicine. ${ }^{10}$ It is important to note that once parentage is established, it is followed by the child's right to be brought up, a right which imposes a duty on the father, namely maintenance.

Many studies ${ }^{11}$ had unanimously agreed that the duty to maintain shall be borne by the father and only in limited situation can this duty be assigned to another party.

In the case of Zainah Mat Ali v. Sapiai Chik, ${ }^{12}$ the court in referring to the book of al-Fiqh-al-Mazahib-al Arba'ah, stated that a father is responsible to provide for the maintenance of his children in the following circumstances:

a) He is able to provide for maintenance,

b) The children are not able to maintain themselves,

c) The father is able to maintain the wife and the children day and night.

9 In article written by Rohanee Machae, Abdul Basir Mohamad, Mutsalim Khareng, "Children Maintenance," 110-112.

10 Nor Halwani v. Muhammad Fathil [2017] 3 SHLR 59.

11 Badruddin Hj. Ibrahim and Azizah Mohd, "Hak Anak Terhadap Nafkah Dalam Perundangan Islam: Sejauh Manakah Bapa Bertanggungjawab Menanggung Nafkah Anaknya," 25 Kanun no. 2(2013): 255; Najibah Mohd Zin, Nora Abdul Hak, Azizah Mohd, Normi Abd Malek, Norliah Ibrahim, Roslina Che Soh @ Yusoff, Norainin Md Hashim, Badruddin Ibrahim, Islamic Family Law in Malaysia (Kuala Lumpur: Sweet \& Maxwell, 2016), 121; Najibah Md. Zin, Noraini Hashim, Nora Abd Hak, Roslina Che Soh, Kamilia Ibrahim, Helmi Md Said, "A Baseline Study of the Enforcement of Nafkah Orders in Selangor Syariah Court," Pertanika Journal of Social Science and Humanities, 23(5)(2015): 327326; Raihanah Azhari, Bahiyah Ahmad, Asmak Ab Rahman.(2012). "Penentuan Kadar Kifayah dan Maaruf Nafkah Anak dan Isteri: Kajian terhadap Penghakiman Mahkamah Syariah," Jurnal Syariah, Jilid.2, bil. 2 (2012): 145-162.

12 Jurnal Hukum 27 Bhgn 11, 1430H: 374. 
The father is obligated to support his wife and children with food, clothing, and shelter regardless of the wife's own resources. Supporting the lives of the wife/wives and children may include providing them with basic necessities, such as food, drink, dress and shelter and other relevant needs. Osborne, J. W through his definition of maintenance has mentioned that maintenance should include, the "Supply of the necessaries of life for a person". ${ }^{13}$ Thus it can be said that the duty to maintain includes to provide for not only food, drink and shelter but also includes providing education, health and other needs. Considering the change in lifestyle that modern society is living in, new items to the list must be added such as fees for access to modern technology and others.

This obligation of a father to give maintenance is stated in the Qur'an that reads as the followings:

Men are protectors and maintainers of women because God has given them the one more than the other, and because they support them from their means [their money]. ${ }^{14}$

In another verse;

Let a man of wealth spend from his wealth, and he whose provision is restricted - let him spend from what Allah has given him. Allah does not charge a soul except [according to] what $\mathrm{He}$ has given it. Allah will bring about, after hardship, ease. ${ }^{15}$

In relation to how much to provide. The following verses in Surah alBaqarah (2), verse 233 mentions; "Upon the father is the mothers' provision and their clothing according to what is acceptable. No person is charged with more than his capacity."

Meanwhile in a hadith narrated by Aishah r.a that Hindun binti Utbah said:

13 In article written by Rohanee Machae, Abdul Basir Mohamad, Mutsalim Khareng, "Children Maintenance," 110-112.

14 Surah An-Nisa: 34. Translation by Muhsin Khan. accessed on May 2, 2021 from https://quran.com/4/34.

15 Surah Al-Talak: 7. Translation by Muhsin Khan. accessed on May 2, 2021 from https://quran.com/65/7. 
O Rasulullah, Abu Sufyan is a stingy man. He did not give my children and me sufficient amount of maintenance unless I took it out of his knowledge. Rasulullah said, take what is sufficient for you and your family in a good manner. (Al Bukhari \& Muslim) $)^{16}$

In another Hadith narrated by Jabir R.A reporting that Prophet Muhammad saw said,

Jabir reported: A person from the Banu 'Udhra set a slave free after his death. This news reached the Messenger of Allah (may peace be upon hhn). Upon this he said: Have you any property besides it? He said: No. Upon this he said: Who would buy (this slave) from me? Nulaim b. Abdullah bought it for eight hundred dirhams and (this amount was) brought to the Messenger of Allah (may peace be upon him) who returned it to him (the owner), and then said: Start with your own self and spend it on yourself, and if anything is left, it should be spent on your family, and if anything is left (after meeting the needs of the family) it should be spent on relatives, and if anything is left from the family, it should be spent like this, like this. And he was saying: In front of you, on your right and on your left. ${ }^{17}$

The above verses and hadith show that it is obligatory (wajib) for a man to provide for his wife and children with maintenance. Maintenance under the Islamic law is generally divided into two. First, is the maintenance necessary for the person himself. It comes before the maintenance a person will give to others. ${ }^{18}$

16 Riyad as Salihin 1535, Book 17. Hadith 25. accessed on May 2, 2021 from http://sunnah.com/search?q=maitenance.

17 Zulkifli Mohamad al Bakri.(2015). Al -Fiqih Al -Manhaji: Kekeluargaan Islam dalam Fiqh Al Shafi'i (Darul Syakir Enterprise, Kuala Lumpur).p. 100.

18 Al Bukhari (6763) and Muslim (997). Laman Rasmi Pejabat Mufti Wilayah. (16 November 2019). accessed on May 2, 2021 from https://muftiwp.gov.my/artikel/al-kafi-lial-fatawi/3804-al-kafi-1428-antara-nafkah-isteri-dan-ibu-mana-perludiutamakan. 
Second, is the maintenance a person has to give to others. That kind of maintenance originates from three reasons:

i) relation due to marriage relation as stated in the Quranic verse: ${ }^{19}$

It is the duty of the father to provide for them and clothe them in a proper manner. ${ }^{20}$

Allow them to reside where you reside, according to your means, and do not harass them in order to make things difficult for them. If they are pregnant, spend on them until they give birth. And if they nurse your infant, give them their payment. ${ }^{21}$

The necessity of providing maintenance is emphasized in the address the Prophet made during the Hajj al-Wida' as provided in the following verse:

Beware of your treatment of women. You have accepted them with the word of Allah... and you have a duty to provide them with reasonable maintenance and clothing. ${ }^{22}$

ii) due to lineage or blood relation as the following Quranic verse:

No mother shall be treated unfairly on account of her child nor father on account of his child, and they shall be chargeable in the same way. ${ }^{23}$

19 Refer also Surah An-Nisa: 34. Translation by Muhsin Khan. accessed on May 2, 2021 from https://quran.com/4/34.

20 Surah al-Baqarah: 233. Al-Quran Al-Karim: Terjemahan \& Tajwid Bewarna (Kuala Lumpur: Karya Bestari), 37.

21 Surah At-Talaq:6. Al-Quran Al-Karim: Terjemahan \& Tajwid Bewarna (Kuala Lumpur: Karya Bestari), 559.

22 Abdur Rahman I. Doi. Women in Shariah (Islamic Law). (A. S Nordeen, Kuala Lumpur: 1992): 108-109; ImÉm Muslim, ØálẾI Muslim (tr.), ÑAbd al HamÊd SiddÊqÊ, KitÉb al-Haj,Vol. II, pp. 615-616.

23 Surah Al-Baqarah (2): 233. Al-Quran Al-Karim: Terjemahan \& Tajwid Bewarna (Kuala Lumpur: Karya Bestari), 37 Please provide full citation of the translation. 
iii) possession over a person (ownership). ${ }^{24}$

Thus, maintenance of children falls under the second category. Under the Shari'ah, the word child is defined as someone who has not reached his or her puberty.

\section{Children who qualify for Maintenance}

The meaning of a child varies according to jurisdiction. According to the Convention on the Rights of the Child (CRC), a child is defined as a person below the age of 18 , unless the relevant laws recognize an earlier age of majority. ${ }^{25}$ Similarly, Malaysia defines a child as a person who is below 18 years old under section 2 of Child Act, $2001 .{ }^{26}$ Under section 2 of the Age of Majority Act 1971, ${ }^{27}$ any person below the age of 18 years old is considered a minor. They are said to have no capacity to enter into any contract. However, this general rule is not absolute and it comes with exceptions. A minor is allowed to enter into a contract of marriage, divorce, dowry and adoption. The other exception of a child is laid down under the case principles ${ }^{28}$ which is any contract for necessaries, contract that brings benefit to the child, such as a scholarship and apprenticeship contract and contract of insurance.

Norazlina Abd. Aziz and Noraini Ismail ${ }^{29}$ agrees that the word "child" as defined above is categorized as such in the eyes of the law for certain reason. The main factors that contribute to such

24 Rohanee Machae, Abdul Basir Mohamad, Mutsalim Khareng, "Children Maintenance," 110-112; Nora Abdul Hak, Roslina Che Soh, Noraini Hashim, "Rights of a Child to Maintenance: Harmonising the Laws in Malaysia" In: Harmonisation of the Shari'ah and Civil laws (perspective and practice), (Kuala Lumpur: IIUM Press, 2009), 243-255; MuÍammad Ibn 'AlÊ ibn MuÍammad al-ShawkÉnÊ, Nayl al-Aü̈Ér,DÉr al-MaÑrifah. Beirut, Lebanon, 1419/1998, Vol. 6, p. 867.

25 Refer to the Convention on the Rights of the Child-UNCRC.

26 Act 611.

27 Act 21.

28 Nash v Inman [1902] 2 KB 1; Doyle v White City Stadium Ltd (1935) 1 KB 110; De Francesco v Branum (1890) 45 Ch D 430; Rajeswary \& Anor $v$ Balakrishnan \& Ors (1958) 3 MC 178.

29 Norazlina Abdul Aziz and Noraini Ismail. "Child Offender: Legal System Approach in Malaysia", a paper presented at the National Seminar on Child Law, Universiti Darul Iman on 13 July 2008. 
categorizations lie on their mental ability to differentiate between what is right and wrong and the ability to foresee future consequences of their act. They are more easily controlled by the emotion rather than a mature adult. ${ }^{30}$ It is axiomatic that children are in the process of growing up, both physically and mentally. Hence, the word child is literally defined as someone who has not reached his or her puberty. It is the responsibility of a father to maintain his daughters until they are married, and sons until they attained the age of puberty. ${ }^{31}$

Nik Noraini ${ }^{32}$ summarized that the method accepted under the Islamic law in determining the adult age of a person, are for a girl, she is legally considered to be major when she begins to menstruate. A girl can start to menstruate at the earliest age of 9. Meanwhile a boy is considered major when he starts getting wet dreams. The lowest age for this would be when he is twelve years old. This is based on the definition of puberty by Imam As-Syafi' $1 .{ }^{33}$

However, according to Nora Abdul Hak, ${ }^{34}$ the right to be maintained is subject to certain conditions. Firstly, that the child still depends on others, as such a father has to maintain his daughter until she marries or has a job. Secondly, that he/she does not possess any assets and is not able to maintain himself/herself. And finally, that the father has the means to maintain his children. In the case where the father is unable to maintain, the duty will transfer to the person liable under hukum syara' to contribute to the maintenance of the children.

30 Irini Ibrahim, Faridah Hussain and Norazlina Abdul Aziz, "The Child Bride: Rights under the Civil and Shariah Law," Procedia - Social and Behavioral Sciences 38 (2012): 53.

31 David Pearl and Werner Menski, Muslim Family Law, $3^{\text {rd }}$ edn. (London: Sweet and Maxwell, 1998), p. 75.

32 Nik Noraini Nik Badli Shah, Marriage and Divorce under Islamic Law, (Kuala Lumpur: International Law Book Services, 1998), https://www.iium.edu.my/deed/hadith/muslim/005_smt.htmlp.133.

33 Rohanee Machae, Abdul Basir Mohamad, Mutsalim Khareng, "Children Maintenance," p.110; Refer also to section 2 of the Laws and Heritage Act in the Southern of Thailand 1947.

34 Nora Abdul Hak, Roslina Che Soh, Noraini Hashim, "Rights of a Child to Maintenance: Harmonising the Laws in Malaysia" paper presented at the $4^{\text {th }}$ Harmonisation of the Shari'ah and Civil Laws (perspective and practice), 8-9 December 2009, AG’s Chambers, Putrajaya, p. 5. 
It can be summarized that the right to maintenance lies on two important conditions that are need of the children and means of the father. According to Ahmad Ibrahim ${ }^{35}$ the duty to maintain depends on the ability of the father ${ }^{36}$ and on the fact that the child is young and unable to maintain himself. Ability is further explained to mean his financial capability after considering his proportion of income to all of his other liabilities. Thus, it is unanimously agreed among the Muslim jurists ${ }^{37}$ that if the children own property and capable to maintain themselves using that property, the father is exempted to provide maintenance for them. This is on the basis that maintenance is provided to those who are in need. ${ }^{38}$ If the children owns property and are able to earn their own living therefore the father is no longer obliged to maintain them. ${ }^{39}$

A father who is already attached to a maintenance order may file for a variation of the original amount of the order. ${ }^{40}$ This occurs when the father's financial status deteriorate. Thus, the court may grant a reduction of the original amount. At this stage, a father still bears the responsibility to maintain his children.

Hence, it is clear that the right of children to maintenance is meant only for the children who have not reached their puberty yet and without any job. Therefore, children who have the capability to work and have reached their puberty, is not entitled to get the maintenance from the father even though they are not working. However, if the

35 Ahmad Ibrahim, Family law in Malaysia, (Kuala Lumpur: Malayan Law Journal Sdn Bhd, 1997), 348-349.

36 Mohd Hassan bin M. Ghazali dan Siti Sharidza Mohd Sidque,(2004), Jurnal Hukum XVIII/II, 271.

37 Sayyidd Sabiq, Fiqh Sunnah, Jilid 8. (Kuala Lumpur: Fathan Prima Media, 2014), 125; Al Kahlawi, Ablah Muhammad, Al-Bunuwwah wa al Ubuwwah fi Daw'al Quran al Karim wa al Sunah (Beirut: Dar alMacrifah, 2005), 169; Wahbah Az-Zuhaili. Al-Figh Ala Al-Islami Wa Adillatuh. Jilid 10 (Beirut: Dar-al-Fikr, 1985), 7418-7419.

38 Interview, February 2018, Syariah High Court, Shah Alam.

39 Najibah Mohd Zin, Nora Abdul Hak, Azizah Mohd, Normi Abd Malek, Norliah Ibrahim, Roslina Che Soh @ Yusoff, Norainin Md Hashim, Badruddin Ibrahim, "Islamic," p.122.

40 Azrina Omar v. Ghazali bin Sharudin [2011] 2 SHLR 61; Khalid lwn Haliman (1978) 1 JH (1) 69. 
children are able to work but they are not working as they are studying, they are entitled to receive the maintenance from their father.

The maintenance of children is basically a form of help from the father, not a rightful giving or tamlik towards a specific right, but it is a form of help, which is tamkin to the children because of the blood relationship. In the other words, if the father did not give maintenance to his children because they forgot to ask for it, or they do not really need it even though the father can afford to give it, it should not be considered as a debt.

The right of a child stems from the lineage of his father. The rights to maintenance, education and others are attached to the existence of a blood relation. The majority of the Muslim scholars agree that children who are entitled to maintenance are those who are the legitimate children of his father. On the other hand, the obligation to provide maintenance to an illegitimate child is on the mother. If the father is unable to maintain, dead or his whereabouts are unknown, the duty shall shift to the male person liable under hukum shara', ${ }^{41}$ namely, the paternal grandfather and the uncles. The duty to maintain will not transfer to the mother even though she has the means as the responsibility shall be transferred to the male persons liable under hukum shara', 42

The Maliki School agrees that the duty to give maintenance is limited to the father. On the other view, the school of Shafie holds a consensual opinion that the ultimate person who bears the obligation to give maintenance shall be the father and if he is not capable of giving maintenance, the obligation shall be shifted to the mother. In a situation where the child has a mother, uncle and grandfather on the paternal side of the family, each of this blood related adult is obliged to give $1 / 3$ of the total maintenance. ${ }^{43}$ The obligation to give maintenance depends on the financial ability of each person.

41 Refer to surah at Talaq: 7 Al-Quran Al-Karim: Terjemahan \& Tajwid Bewarna (Kuala Lumpur: Karya Bestari), 559; Muhammad bin Ismail AlAmir Ash-Shan'ani, Subulus Salam (Syarah Bulughul Maram). Jilid 3. (Indonesia: Darus Sunnah, 2015), 1214.

42 Nora Abdul Hak, Roslina Che Soh, Noraini Hashim, "Rights of a," 243.

43 Nora Abdul Hak, Roslina Che Soh, Noraini Hashim, "Rights of a," 3. 


\section{ISLAMIC LEGAL INTERPRETATION OF PATERNAL FAMILY RELATING TO MAINTENANCE PURPOSES}

The role of the paternal relation as guardian in the absence of the father is an important stage to invoke financial responsibility borne by family members towards minors or the disabled. ${ }^{44}$ The majority of Muslim jurists are of the opinion that the responsibility of providing maintenance to children will transfer to the paternal family members. The authority used by the majority Muslim jurists in determination of responsibilities of the paternal family member to provide for maintenance of the children, is linked to the rule of inheritance under Islam where some of them are eligible to inherit from one another. The children have a blood and lineage relationship with other members of their father's family in a way similar to what they have with the father. ${ }^{45}$

In contrast, the Maliki's jurists are of the opinion that the liability to maintain the children shall be retained with the father and not transferable to other next of kin be it on paternal or maternal side of the parents as quoted in the article by Najibah Mohd Zin and et al. ${ }^{46}$ The reason for his opinion lays on the rule that the duty to provide maintenance shall be developed at the outset and not by transmission from the father to his family member.

Although, the majority of the Muslim jurists agreed that the duty to maintain is transferable to the next of kin, they hold different opinions in the determination of the family members who shall be liable for maintenance. The Shafie jurists opined that the duty is shifted to relatives from lineal kinship. ${ }^{47}$ On the other hand, the Hanafi's

44 Najibah Mohd Zin, "Regulating the Role of Extended Families in Providing Financial Support under Malaysian Law," 16 International Islamic University Malaysia (IIUMJ), (2008): 109; Gisela Webb, Windows of Faith: Muslim Women Scholar Activists in North America, (New York: Syracuse University Press, 2000), 263.

45 Najibah Mohd Zin, Nora Abdul Hak, Azizah Mohd, Normi Abd Malek, Norliah Ibrahim, Roslina Che Soh@ Yusoff, Noraini Md Hashim, Badruddin Ibrahim, "Islamic," 122.

46 Ibid.

47 Muwafiquddin Ibnu Qudamah al-Maqdisi, Al Mughni, vol. 7, bab alnafaqat tahqiq Dr. Muhammad Syarafuddin Khathab, Dr. Sayyid 
school holds to the thought that maintenance shall be borne by family members who are in prohibited degree of marriage. Meanwhile, the Hanbali school of thought uses inheritance as the ground to identify the duty to provide for maintenance. ${ }^{48}$

In Malaysia, the court follows after the Practice Direction No. 14 of 2007 that stated person who is said to be responsible under hukum syarak that can be ordered to pay the maintenance of a specified person in accordance to the rules of Islamic Family law, are the male heirs known as asobah (residuary) under the Faraid (group in the inheritance of a person based on priority) rules. In a situation where the paternal family is unable to pay for the maintenance, then the responsibility can be assigned to the Baitulmal. In the case of Rohana bt Zakaria $v$. Mokhtar bin Abdul Talib, ${ }^{49}$ the wife applied for revised of courts' order on the amount of maintenance of their children. When the divorce took place, the children are infants and as they are now starting schooling, the previous amount is insufficient. In delivering the judgment, the court defined the person liable under hukum shara' can be extended to the legal heirs of the children. The judgment in this case was made referring to the authority from surah al-Baqarah: 233, as follows:

...the same duty rests upon the heir...

Following the strong authority from the Quranic verse quoted, it can be said that Islam extended the duty to maintain children to the legal heirs in situation where the father could not afford. The paternal grandfather takes the lead followed by the rest of family members from the male paternal relations as the Shariah law allotted for them some shares in inheritance property. The Quran states:

Muhammad Sayyid, dan Prof. Sayyid Ibrahim Shadiq (Pustaka Azzam, Indonesia: 2016).

48 As quoted in the book of Najibah Mohd Zin, Nora Abdul Hak, Azizah Mohd, Normi Abd Malek, Norliah Ibrahim, Roslina Che Soh @ Yusoff, Noraini Md Hashim, Badruddin Ibrahim, "Islamic," 109.

49 (2009) 27 Jurnal Hukum (II) 279. 
From what is left by parents and those nearest related there is a share for men and a share for women, whether the property is small or large, a determinate share. ${ }^{50}$

Those who are entitled to inheritance property, as suggested in the above verse, include the extended family such as brothers, uncles and cousins, besides fulfilling his own liability to support his wife and children. This entitlement to inheritance property incorporates a legal responsibility to support financially the needs of minor children of the deceased if they encounter financial difficulties. Allotment of responsibility through inheritance is explained in the Quran that reads as follows:

Allah instructs you concerning your children: for the male, what is equal to the share of two females. But if there are [only] daughters, two or more, for them is two thirds of one's estate. And if there is only one, for her is half. And for one's parents, to each one of them is a sixth of his estate if he left children. But if he had no children and the parents [alone] inherit from him, then for his mother is one third. And if he had brothers [or sisters], for his mother is a sixth, after any bequest he [may have] made or debt. Your parents or your children - you know not which of them are nearest to you in benefit. [These shares are] an obligation [imposed] by Allah. Indeed, Allah is ever Knowing and Wise. ${ }^{51}$

In case of an orphaned child, the burden shifts to the grandparents. Where the grandparents are dead or unable to provide maintenance to the child, the obligation devolves on the collateral relations of the child. However, the obligation is restricted to the collaterals within the prohibited degrees of relationship by priority of being entitle to inherit from the child had the child been dead. ${ }^{52}$ These relations primarily include uncles and aunts of the child and to provide maintenance to the

50 Surah An- Nisa:7 Translation by Muhsin Khan. accessed on May 2, 2021 from https://quran.com/4/34.

51 Surah An-Nisa :11 Translation by Muhsin Khan. accessed on May 2, 2021 from https://quran.com/4/34.

52 Shabina Arfat, "Islamic Perspective of the Children's Rights: An Overview". Asian Journal of Social Sciences and Humanities, vol.2. No.1 (2013): 299. 
child, their liability is joined, but proportionate to the share of each in the property of the child had it been dead.

According to the school of Hanafi, if the father is not capable to provide for maintenance of the children by reason of health or poverty, the maintenance shall be borne by the paternal grandfather or the mother to the children. The amount of maintenance provided by the paternal grandfather or the mother then become the debt of the father. In situation where both mother and the paternal grandfather provide for the maintenance the division of the claimable debt is $1 / 3$ for the mother and $2 / 3$ for the paternal grandfather. ${ }^{53}$

\section{THE RIGHTS OF CHILDREN TO MAINTENANCE UNDER THE ISLAMIC FAMILY LAW (SELANGOR) ENACTMENT 2003}

Section 73(1) of the Islamic Family Law (Selangor) Enactment 2003 (IFLS) provides that the father is obligated to support his wife and children with food, clothing, and shelter following his ability and reasonableness of the situation. Despite having this provision, there have been reports that stated on the abandoned children without means of support. ${ }^{54}$ In this case, the couple has eight biological children and one adopted child. Upon divorce, the father took custody two of the biological children and the rest remain under the custody of the mother. The ex-wife and children were abandoned without any means of support.

Section 73(1) of IFLS clearly specifies that it is the duty of the father to maintain his children whether they are in his custody or the custody of other person, as it is reasonable having regards to his means and station in life or paying the cost incurred. Maintenance according to the provision includes accommodation, food medical attention, and education. However, subsection 2 of the same provision stated that

Except as aforesaid, it shall be the duty of a person liable under Hukum Syara', to maintain and contribute to the maintenance of

53 As quoted in the book of Najibah Mohd Zin, Nora Abdul Hak, Azizah Mohd, Normi Abd Malek, Norliah Ibrahim, Roslina Che Soh @ Yusoff, Noraini Md Hashim, Badruddin Ibrahim, "Islamic," 109-110.

54 Harian Metro, December 28, 2013. 
children if their father is dead or his where about is unknown or if and so far, as he is unable to maintain them.

The above provision authorizes the court to order 'a person liable under the Hukum Syara' to pay where the root of the principle refers to those who are entitled to inheritance property depending on his status in the family. Hukum Syarak means the law recognized by the four major schools of law i.e., Shafie, Hanafi, Maliki and Hanbali.

In utilizing and interpreting the above provision, most of the informants working as Shariah legal practitioners and Shariah court judges emphasized on this limitation by integrating it to the principle that the father should only maintain his child who is not able to maintain himself. Thus, a child who owns property and has sufficient income to enjoy fair living is disqualified to claim for maintenance from his father. For example, a child who is a beneficiary of his grandfather's estate or children who work in the entertainment industry will be disqualified to claim. This is in line with the above stated authorities.

\section{BARRIERS TO THE CLAIM MADE UNDER SECTION 73(2) OF ISLAMIC FAMILY LAW (SELANGOR) ENACTMENT 2003}

\section{a) Awareness on the right to claim}

Informant from the Shariah high court of Selangor discloses there are not many cases involving the application of maintenance of the children to the extended family or the baitulmal. This is due to lack of awareness on the existence and application of the law on this matter. In usual cases the claimant would claim maintenance from the father and the court would issue an order accordingly. Not many theological study or social science study that dispersed knowledge on the responsibility to maintain children to marriage can be imposed of the paternal side of the family. When the ex-husband cannot be located, no action is further pursued. Most of the time, legal action stops there and no further action are taken. ${ }^{55}$ Many women refused to take legal actions for several reasons such as, they were not willing to undergo the tedious

55 Najibah Md. Zin, Noraini Hashim, Nora Abd Hak, Roslina Che Soh, Kamilia Ibrahim, Mohd Helmi Said, “A Baseline,” 328. 
and costly court proceedings in order to get a relatively small amount of money that they had bargained for, or they just did not bother to lodge complaints against the ex-husbands, or they did not know that there exist several legal provisions to enforce their financial rights. ${ }^{56} \mathrm{In}$ addressing the issue of lack of awareness it can be suggested that the Family Support Unit under the Syariah Court, which serves as a onestop centre to handle issues on family and divorce cases can assist in educating the society on this need. This is in line with the role of this unit, which is to simplify and expedite court procedures when it involves the issue of unpaid maintenance.

\section{b) Baitulmal inadequate tracing system}

Baitulmal is an Islamic agency that is responsible to receive and generate income to the needy among Muslim. It's a useful institution that can offer financial assistant to children who has lost their financial support. Nevertheless, baitumal is lacking of an effective tracing system that can trace the needy among the Muslim population. Thus by naming baitumal as the defendant to the claim for maintenance, baitulmal is supplied with the information of the needy children. Baitulmal will become the party to the suit when order to pay maintenance has been made to the defaulting father and his whereabouts are unknown. The plaintiff can later name baitulmal as the defendant to the claim. According to the informants of this study,the baitulmal would usually comply with the claim without contesting in court. Nevertheless prior to the agreement to provide maintenance,the baitulmal would usually conduct an investigation on the claiming party.

\section{c) Unclear scope of person responsible under Hukum Syarak}

The Islamic Family Law (Selangor) Enactment 2003 is absent in providing for the definition of "person liable under hukum syara". The law lays down a general provision on the duty of another person who

56 Muslihah Hasbullah and Najibah Mohd Zin, "How Divorced Women Can Effectively Enforce the Financial Support Orders: The Legal and Administrative Actions," International Journal of Humanities and Social Science, vol.2, no.13(2012): 145. 
is liable under Islamic law in general to maintain a child after the death of his parents. ${ }^{57}$ It was only through discussion with the Shariah legal practitioner and shariah court judge and analyzing legal cases that the elaboration of "the person liable under hukum syara" submerged. Applying the experience of the researchers (who received legal education), it can be said that a layman without legal education would not have known to whom the claim should be addressed in cases where children to the family loses their means of maintenance.

\section{d) Inadequate reporting and recording system of the Shariah court}

The claim for maintenance of children is usually made in Shariah Lower Court. The court allows the claim to be made in two ways. The first is making the child himself as the plaintiff and secondly by the children's mother or guardian ad litem. ${ }^{58}$ If the mother is made as plaintiff, tracing the file for maintenance would be difficult as the court do not maintain an organized record of all claims made in the Shariah court. Claims at the Shariah Court have indicated gaps and loopholes in the laws, especially in the procedures concerning the enforcement of the nafkah court orders. ${ }^{59}$

\section{e) Loosen relation with the paternal side of the family}

The claim for maintenance of the children is usually made following divorce cases. Normally, if the mother were granted with the right to custody, the children would have a bland relationship with the paternal side of the family. The mother and her family would usually avoid having any continuity of relationship with the ex-husband and his family. This contributes to the lack of claim for maintenance made to the paternal side of the children. According to Najibah Md Zin ${ }^{60}$ the dilution of the big family units that have been replaced by separate and

57 Mohd, Normi Abd Malek, Norliah Ibrahim, Roslina Che Soh @, Yusoff, Norainin Md Hashim, Badruddin Ibrahim, “Islamic," 124.

58 Interview, (YA Zulkifli b. Yasoa ) February 2018, Shariah High Court, Shah Alam.

59 Interview, (YA Zulkifli b. Yasoa) February 2018, Shariah High Court, Shah Alam.

60 Najibah Mohd Zin, "Regulating the Role," 109. 
individual living style have contributed to vulnerable bonding between immediate families with other blood related family members. Other than the transformation of the family unit composition, the $21^{\text {st }}$ century lifestyle has also contributed to the gap in the relation between individual within the same family. Thus, the sense of responsibility became diluted with this widening gap between family members.

\section{f) Insufficient income of the Paternal Side of the family}

In deciding the amount of maintenance for the wives and children, the Malaysian Shariah courts will consider few factors that include the ability of the father to pay for maintenance ${ }^{61}$ the social class of the wife and the actual needs of the wife and children. ${ }^{62}$ The ability of the husband is later evaluated in view of the father's property and source of income. The duty to earn an income is limited to his physical and mental health. If he is temporary not able to secure an income due to health reason, the maintenance of his family can be shifted to his immediate male family member following the inheritance hierarchy. The maintenance given by his immediate family becomes his debt. When the whereabouts of the father is unknown, the order to pay maintenance made to the father can be shifted to his family by applying for assignment order from the court ${ }^{63}$. However, this assignment is also limited to the ability of the maintenance payer to afford. If the male family of the father faces financial difficulties to maintain his extended family, the assignment order will not be imposed to the male family instead naming baitulmal as the defendant to the suit.

61 Mohd Hassan bin M. Ghazali dan Siti Sharidza Mohd Sidque,(2004), Jurnal Hukum XVIII/II, 275 .

62 Najibah Md. Zin, Noraini Hashim, Nora Abd Hak, Roslina Che Soh, Kamilia Ibrahim, Mohd Helmi Said, "A Baseline Study of the Enforcement of Nafkah Orders in Selangor Syariah Court," Pertanika Journal of Social Science and Humanities, 23(5) (2015): 327-326; Raihanah Azhari, Bahiyah Ahmad, Asmak Ab Rahman. (2012). "Penentuan Kadar Kifayah dan Maaruf Nafkah Anak dan Isteri: Kajian terhadap Penghakiman Mahkamah Syariah,” Jurnal Syariah, Jilid.2, bil. 2 (2012): 146.

63 Interview, YA Zulkifli b. Yasoa February 2018, Shariah High Court, Shah Alam. 


\section{g) Weaknesses in Enforcement of Order}

As generally observed, although a nafkah order is granted by the Shariah Court, the claimant is unable to execute the order immediately. The plaintiff must initiate other proceedings to execute the order, which entails more delays and incurs higher cost. Worse still, even after getting the execution order, the defendant may not still comply with the order, rendering more hardship for the frustrated claimant as well as the court because the order had not been enforced. The problem is further aggravated when there is lack of an appropriate support system to alleviate the problems faced by the claimant. ${ }^{64}$

\section{CONCLUSION AND POLICY RECOMMENDATIONS}

From the discussion above, it can be summarized that there is a need to elevate the current laws and practice addressing issue of children maintenance specifically using section 73(2) of the Islamic Family Law (Selangor) Enactment 2003. The laws, which are in place, are somewhat insufficient as a means of assisting the needy children due to technicality issues and the effective application of the existing laws. It has been highlighted that there is lack of awareness on the claimant (mother and children) on the responsibility of the extended family. Thus, to this deficiency extending the role of Family Support Unit, a unit that is assigned with the task to assist family related issues can be the feasible short-term recommendation. The role in educating the claimant can be shared with the baitulmal. Information management system that has been an inherent issue within the shariah courts has in a way contributed to the efficiency system of both the Shariah courts and Islamic agency like baitulmal. It is a known fact that this problem has emerged due to the lack of financial support. Thus, revise of fund allocation to the management of Shari'ah court is a good assistance. On inadequacy of the current statute, inserting a clear definition of 'people responsible under hukum syara' will assist in information seeking activity. The main aim of these recommendations is to ease the burden of the unfortunate children and the mother who suffered sudden loss of financial sources. To this ill-fated scenario, is attached many other rights of the children such as the right to education, right to be free

64 Interview, YA Zulkifli b. Yasoa February 2018, Shariah High Court, Shah Alam. 
from slavery and rights to enjoy a decent life. The children future will be put at stake to grow having defected emotional quality. This will, in a way defame the dignity of Islam as the protector of children. 